\title{
Prolonged Viral Shedding of Influenza Virus: Which Definition?
}

\author{
Macé M Schuurmans ${ }^{1^{*}}$ and Nicolas $\mathrm{J} \mathrm{Mueller}^{2}$
}

${ }^{1}$ Division of Pulmonary Medicine, University Hospital Zurich, Raemistrasse 100, 8091 Zurich, Switzerland

${ }^{2}$ Division of Infectious Diseases and Hospital Epidemiology, University Hospital Zurich, Raemistrasse 100, 8091 Zurich, Switzerland

*Corresponding author: Macé M Schuurmans, Division of Pulmonary Medicine, University Hospital Zurich, Raemistrasse 100, 8091 Zurich, Switzerland, Tel: 442554126, E-mail: Mace.Schuurmans@usz.ch

Rec date: Nov 07, 2014, Acc date: Nov 25, 2014, Pub date: Nov 27, 2014

Copyright: @ 2014 Schuurmans MM. This is an open-access article distributed under the terms of the Creative Commons Attribution License, which permits unrestricted use, distribution, and reproduction in any medium, provided the original author and source are credited.

\begin{abstract}
Influenza virus infection poses a considerable risk for complications to the general population and in particular to solid organ transplant recipients (SOTR). Life-long immunosuppression in SOTR likely contributes to delayed clearance of influenza virus from the airways: Prolonged Viral Shedding (PVS) has important implications for potential infectivity and infection control measures. Duration of infectivity as measured by viral culture has been reported to last 4-6 days in the non-transplant setting. Shedding measured by Polymerase Chain Reaction (PCR) in immune competent patients is similar, 5-6 days. To date there is no recommended or widely accepted definition of PVS for influenza virus infections. The lack of a PVS definition makes comparisons between studies difficult. Most studies assess shedding duration by serial PCR of nasopharyngeal swabs. A number of studies calculate shedding from the time of onset of symptoms to the last positive detection. Shedding is considered to be "prolonged" if it continues on or beyond day 7 or 14 . However, considerable variability exists in defining PVS. A large number of studies rely on two objective measures to define the duration of shedding: This requires at least two positive detections of viral material, usually by PCR. We discuss the different aspects of these definitions and propose a practical definition that takes into account a number of factors relevant to the topic.
\end{abstract}

Keywords: Influenza virus; Prolonged viral shedding; Diagnosis; Definition; Solid organs transplant recipients

\section{Introduction}

Influenza virus infection poses a considerable risk for complications to the general population and in particular to Solid Organ Transplant Recipients (SOTR). Yearly vaccination against influenza virus and early detection and treatment in case of suspected or proven infection are recommended strategies to prevent complications among SOTR [1]. Life-long immunosuppression in SOTR likely contributes to delayed clearance of influenza virus from the airways: Prolonged Viral Shedding (PVS) has important implications for potential infectivity and infection control measures. Preventing nosocomial transmission of influenza virus among SOTR is a concern [1]. Duration of infectivity as measured by viral culture has been reported to last 4-6 days in the non-transplant setting [2]. Shedding measured by Polymerase Chain Reaction (PCR) in immune competent patients is similar, 5-6 days [3-5]. Shedding may extend beyond the symptomatic period. To date there is no recommended or widely accepted definition of PVS for influenza virus infections. The lack of a PVS definition makes comparisons between studies difficult. This is an increasing problem as the body of literature grows in this field of research.

Most studies assess shedding duration by serial PCR of nasopharyngeal swabs. Currently, two main strategies are used to determine duration of shedding. A number of studies calculate shedding from the time of onset of symptoms (OS) to the last positive detection. A correct determination of the end of shedding relies on microbiological detection of virus material whereby the last detection of virus followed by a negative test result defines the end of shedding [6]. Shedding is considered to be "prolonged" if it continues on or beyond day 7 or 14 [7-9]. However, considerable variability exists in defining PVS (Table 1).

\begin{tabular}{|l|l|}
\hline Author, Year, Reference & Cutoff to define PVS \\
\hline Lee N, 2009 [16] & $\geq 5$ days OS \\
\hline Meschi S, 2011 [15] & $>6$ days OS \\
\hline Gianella M, 2010 [12] & $\geq 7$ days VM \\
\hline Schuurmans MM, 2014 [11] & $\geq 7$ days VM \\
\hline Leekha S, 2007 [14] & $\geq 7$ days OS \\
\hline Chin BS, 2012 [8] & $>7$ days OS \\
\hline Souza TML, 2010 [7] & $>7$ days VM \\
\hline Carr S, 2011 [9] & $\geq 14$ days VM \\
\hline Choi SM [13] & $>14$ days VM \\
\hline $\begin{array}{l}\text { Note: PVS: Prolonged Viral Shedding; OS: Onset of Symptoms; Duration of } \\
\text { shedding calculated from the onset of symptoms. VM: Viral Material; Duration of } \\
\text { shedding is calculated from first detection of viral material. }\end{array}$ \\
\hline
\end{tabular}

Table 1: Selected definitions of prolonged viral shedding for influenza infections.

Using OS to define the start of shedding assumes that shedding actually coincides with the onset of symptoms. This assumption is widely accepted and supported by data [2,3]. One advantage of this definition is that it encompasses the patient-related delay between OS and physician consultation, the first potential opportunity for virological sampling. This delay typically is approximately 2 days and 
may be shorter for SOTR [10,11]. Determining duration of shedding by this way may be considered practical or pragmatic because it considers usual patient behavior and the clinical course.

Using a second strategy, a considerable number of studies rely on two objective measures to define the duration of shedding [7,9,11-13]: This requires at least two positive detections of viral material (VM), usually by PCR. In serial sampling, the first and the last positive detection will define the duration [11]. This method determining the shedding duration may be considered more reliable and objective, and generally would be only feasible in specific settings with regular sampling, such as for SOTR or for research purposes.

For both strategies (OS or VM), the cutoff duration defining PVS must be slightly longer than what is usually considered the normal duration of shedding of influenza virus (5-6 days). Therefore, the definition using 7 days or longer appears to be most appropriate to define PVS.

We propose to use the onset of symptoms as the starting point, and the last positive sample (followed by a negative) as total duration. Prolonged viral shedding starts at day 7. A common definition would allow comparing studies needed for many relevant clinical questions. Following this definition it would make sense to sample one week after OS. The sampling result may also influence the duration of antiviral treatment, since prolonged treatment has been recommended for SOTR under certain circumstances [1]. Usual treatment duration with oseltamivir is 5 days so this time frame may influence the timing of the sampling strategy.

A number of factors are known to prolong shedding duration, such as presence of pneumonia, immunosuppression, delayed or absence of antiviral treatment and pediatric age $[9,11-13,17]$. Many aspects of PVS of influenza virus remain to be determined and having a consensus on what defines PVS may stimulate research and debate in this field. The time is ripe for a consensus definition on PVS from one of the infectious disease societies!

\section{Author contributions}

MMS: Concept, data compilation, manuscript preparation and revisions. NJM: Critical manuscript review and revisions.

\section{References}

1. Kumar D, Blumberg EA, Danziger-Isakov L, Kotton CN, Halasa NB, Ison MG, et al. (2011) AST Infectious Diseases Community of Practice. Influenza vaccination in the organ transplant recipient: review and summary recommendations. Am J Transplant: 2020-2030

2. Suess T, Remschmidt C, Schink SB, Schweiger B, Heider A, et al. (2012) Comparison of shedding characteristics of seasonal influenza virus (sub)types and influenza A(H1N1)pdm09; Germany, 2007-2011. PLoS One 7: e51653.
3. Witkop CT, Duffy MR, Macias EA, Gibbons TF, Escobar JD, et al. (2010) Novel Influenza A (H1N1) outbreak at the U.S. Air Force Academy: epidemiology and viral shedding duration. Am J Prev Med 38: 121-126.

4. Ling LM, Chow AL, Lye DC, Tan AS, Krishnan P, et al. (2010) Effects of early oseltamivir therapy on viral shedding in 2009 pandemic influenza A (H1N1) virus infection. Clin Infect Dis 50: 963-969.

5. Yu H, Liao Q, Yuan Y, Zhou L, Xiang N, et al. (2010) Effectiveness of oseltamivir on disease progression and viral RNA shedding in patients with mild pandemic 2009 influenza A H1N1: opportunistic retrospective study of medical charts in China. BMJ 341: c4779.

6. Ryoo SM, Kim WY, Sohn CH, Seo DW, Oh BJ, et al. (2013) Factors promoting the prolonged shedding of the pandemic (H1N1) 2009 influenza virus in patients treated with oseltamivir for 5 days. Influenza Other Respir Viruses 7: 833-837.

7. Souza TM, Salluh JI, Bozza FA, Mesquita M, Soares M, et al. (2010) H1N1pdm influenza infection in hospitalized cancer patients: clinical evolution and viral analysis. PLoS One 5: e14158.

8. Chin BS, Chae YT, Choi HK, Baek JH, Jin SJ, et al. (2012) Viral shedding of 2009 pandemic $\mathrm{H} 1 \mathrm{~N} 1$ and evaluation of quarantine recommendations. Jpn J Infect Dis 65: 105-110.

9. Carr S, Ilyushina NA, Franks J, Adderson EE, Caniza M, et al. (2011) Oseltamivir-resistant influenza $\mathrm{A}$ and $\mathrm{B}$ viruses pre- and postantiviral therapy in children and young adults with cancer. Pediatr Infect Dis J 30: 284-288.

10. Kumar D, Michaels MG, Morris MI, Green M, Avery RK, Liu C,et al.American Society of Transplantation H1N1 Collaborative Study Group. Outcomes from pandemic influenza A H1N1 infection in recipients of solid-organ transplants: a multicentre cohort study. Lancet Infect Dis. 2010 Aug;10:521-526

11. Schuurmans MM, Isenring BD, Jungo C, Boeni J, Mueller NJ, et al. (2014) Clinical features and outcomes of influenza infections in lung transplant recipients: a single-season cohort study. Transpl Infect Dis 16: 430-439.

12. Giannella M, Alonso M, Garcia de Viedma D, Lopez Roa P, Catalán P, et al. (2011) Prolonged viral shedding in pandemic influenza $A(H 1 N 1)$ : clinical significance and viral load analysis in hospitalized patients. Clin Microbiol Infect 17: 1160-1165.

13. Choi SM, Boudreault AA, Xie H, Englund JA, Corey L, et al. (2011) Differences in clinical outcomes after 2009 influenza A/H1N1 and seasonal influenza among hematopoietic cell transplant recipients. Blood 117: 5050-5056.

14. Leekha S, Zitterkopf NL, Espy MJ, Smith TF, Thompson RL, et al. (2007) Duration of influenza A virus shedding in hospitalized patients and implications for infection control. Infect Control Hosp Epidemiol 28: 1071-1076.

15. Meschi S, Selleri M, Lalle E, Bordi L, Valli MB, et al. (2011) Duration of viral shedding in hospitalized patients infected with pandemic H1N1. BMC Infect Dis 11: 140.

16. Lee N, Chan PK, Hui DS, Rainer TH, Wong E, et al. (2009) Viral loads and duration of viral shedding in adult patients hospitalized with influenza. J Infect Dis 200: 492-500.

17. Cao B, Li XW, Mao Y, Wang J, Lu HZ, et al. (2009) Clinical features of the initial cases of 2009 pandemic influenza A (H1N1) virus infection in China. N Engl J Med 361: 2507-2517. 